\title{
Synthesis of allobetulin conjugates with unsaturated acids
}

\author{
C Marina P. Yakovleva, ${ }^{1 *+}$ Valentina A. Vydrina, ${ }^{1}$ Rasul R. Sayakhov, ${ }^{1}$ \\ Natalia I. Medvedeva, ${ }^{1}$ Aidar R. Khafizov, ${ }^{2}$ and Gumer Yu. Ishmuratov ${ }^{1}$ \\ ${ }^{1}$ Ufa Institute of Chemistry of the Ufa Federal Research Center of the Russian Academy of Sciences. \\ October Ave., 71. Ufa, 450054. Republic of Bashkortostan. Russia. \\ Phone:+7 (8347) 235-58-01.E-mail:insect@anrb.ru \\ ${ }^{2}$ Bashkir State University. Mingazheva St., 100. Ufa, 450078. Republic of Bashkortostan. Russia.
}

\begin{abstract}
*Supervising author; ${ }^{+}$Corresponding author
\end{abstract}
Keywords: betulin, allobetulin, 9-oxo-2E-decenoic, citronella and geranium acids, conjugates.

\begin{abstract}
A conjugate is an artificially chemically synthesized hybrid molecule in which two (or more) molecules with different properties are connected; widely used in medicine and experimental biology. Recent years have given reason to pin hopes on introducing into the therapy a number of socially significant diseases of drugs based on pentacyclic triterpenoids, which constitute an important class of natural compounds with a wide spectrum of biological activity. The betulin isomer related to them, allobetulin, exhibits moderate inhibitory activity against influenza B virus and antichlamydia activity. Its derivatives have antiulcer, antiviral and immunoregulatory activity. A promising direction in the synthesis of biologically active substances is the formation of an ester group, which allows the construction of substances with new or enhanced basic biological activity. Thus, the synthesis of allobetulin esters with unsaturated bioactive acids is of interest.

Our study presents the synthesis of allobetulin esters with unsaturated acids - geranium, 9-oxo- $2 E$ decenoic and 10-undecenoic. The selection of these acids was not random. So, 10-undecenoic acid has a fungistatic and fungicidal effect against fungi of the genera Candida spp, Trichophyton spp., Microsporum spp., Epidermophyton spp., Scopulariopsis spp. Geranium (3,7-dimethyllocta-2,6-dienoic) acid is characterized by antibacterial and antifungal, as well as cytotoxic activity against cancer cells of the pancreas, colon, liver, skin and leukemia. 9-Oxo-2E-decenoic acid, being a multifunctional pheromone of honeybees, exhibits a wide range of pharmacological properties: antibacterial, antidote, anti-inflammatory, accelerator of healing of patchwork wounds and thermal burns, immunomodulator (on warm-blooded animals) and anti- varroatosis, anti-fungal, (on honey bees). We suggested that the combination of allobetulin fragments with the residues of the above biologically active acids in one molecule can enhance the existing pharmacological properties and/or contribute to the emergence of other biological activity. We proposed the synthesis of conjugates of allobetulin and the aforementioned biologically active unsaturated acids, based on the conversion of the latter to the corresponding acid chlorides by the action of an excess of thionyl chloride and their subsequent interaction with allobetulin in pyridine in the presence of catalytic amounts of dimethylaminopyridine.
\end{abstract}

\section{References}

[1] M. Zhou, R.-H. Zhang, M. Wang, G.-Bo Xu, S.-G. Liao. Eur. J. Med. Chem. 2017. Vol.131. P.222-236.

[2] W. Dehaen, A.A. Mashentseva, T.S. Seitembetov. Molecules. 2011. Vol.16. No.3. P.2443-2466.

[3] O. Salin, S. Alakurtti, L. Pohjala, A. Siiskonen, V. Maass, M. Maass, J. Yli-Kauhaluoma, P. Vuorela. Biochem. Pharmacol. 2010. Vol.80. No.8. P.1141-1151.

[4] O.B. Flekhter, N.I. Medvedeva, L.T. Karachurina, L.A. Baltina, F.Z. Galin, F.S. Zarudii, G.A. Tolstikov. Pharm. Chem. J. 2005. Vol.39. No.8. P.401-404.

[5] N.V. Galayko, I.A. Tolmacheva, V.V. Grishko, L.V. Volkova, E.N. Perevozchikova, S.A. Pestereva. Russ. J. Bioorg. Chem. 2010. Vol.36. No.4. P.516-521.

[6] S.V. Gein, V.V. Grishko, T.A. Baeva, I.A. Tolmacheva. Int. J. Pharmacol. 2013. Vol.9. No.1. P.74-79.

[7] R.M. Carlson. Patent US 6369101 B1. 2002. [CA 2002, 136, 279583].

[8] Undecylic acid. Chemical encyclopedic dictionary. Ch. ed. Klunyants I.L. Moscow: Soviet encyclopedia. 1983.792p. (russian)

[9] B. Barycza, A. Pawlak, D. Poradowski, B. Obmińska-Mrukowicz, C. Wawrzeńczyk. Przem. Chem. 2013. Vol.92. No.5. P.806-812.

[10] G.Yu. Ishmuratov, V.A. Vydrina, G.V. Nasibullina, M.P. Yakovleva, R.R. Muslukhov, G.A.Tolstikov. Chem. Nat. Compd. 2011. Vol.47. No.5. P.789-791. 
[11] T.-S. Li, J.-X. Wang, X.-J. Zheng. J. Chem. Soc. Perkin Trans. I. 1998. No.23. P.3957-3865.

[12] D.J. Anneken, S. Both, R. Christoph, G. Fieg, U. Steinberner, A. Westfechtel. "Fatty Acids" in Ullmann's Encyclopedia of Industrial Chemistry. Wiley-VCH, Weinheim. 2006. Vol.14. P.73.

[13] Вейганд - Хильгетаг. Методы эксперимента в органической химии. М.: Химия. 1968. 944c. 